\title{
Current endoscopic techniques in the treatment of obesity
}

\author{
Eduardo Espinet-Coll ${ }^{1}$, Javier Nebreda-Durán ${ }^{1}$, José Antonio Gómez-Valero ${ }^{1}$, Miguel Muñoz-Navas², \\ Jordi Pujol-Gebelli ${ }^{3}$, Carmen Vila-Lolo ${ }^{1}$, Antonio Martínez-Gómez ${ }^{1}$ and Antonio Juan Creix-Comamala ${ }^{1}$ \\ ${ }^{1}$ Unit of Endoscopy. Gastrodex. Hospital Universitario Dexeus. Barcelona, Spain. ${ }^{2}$ Unit of Endoscopy. \\ Clínica Universitaria de Navarra. Pamplona, Spain. ${ }^{3}$ Unit of Bariatric and Metabolic Surgery. \\ Hospital Universitario de Bellvitge. L'Hospitalet. Barcelona, Spain
}

\begin{abstract}
Background: in recent years new endoscopic strategies and techniques for the treatment of obesity have emerged and developed.

Aim of the study: in this article we will review and analyze the current state of the following techniques and the basic differential characteristics between each of them: balloons and prosthesis, injection of substances, systems of sutures, malabsorptives techniques and others currently in research.

Methods: we will evaluate the endoscopic technique and their main indications, results, tolerances, complications and adverse effects observed, reporting our personal experience and in relation with an extensive literature review.

Results: comparatively with the most widespread technique of the Bioenterics balloon, the Spatz balloon can provide greater weight loss but with worse tolerance and more complications and the Heliosphere Bag gets a similar weight loss but with greater technical difficulty. Other balloons and prosthesis (Ullorex, Semistationary, Silimed, Endogast) still require technical improvements and higher studies. The injection of botulinum toxin, although secure, seems to offer a smaller and more transient efficacy. Suture systems (TOGa, endoluminal vertical gastroplasty and POSE) appear to be effective but are technically more laborious. Malabsorptives procedures (Endobarrier, ValenTX) are somewhat laborious but effective, particularly indicated in obese patients with type 2 diabetes mellitus.

Conclusions: the development of new endoscopic techniques and improvement in existing designs, suggest an increasingly important role of the endoscopist in the treatment of obesity. We consider it important to individually select and use the endoscopic technique, depending on the desirable outcomes (efficacy, tolerance, safety, adverse effects and risks) and the experience of each hospital. We believe that these techniques should be applied by specifically trained endoscopists in specialized hospitals.
\end{abstract}

Key words: Endoscopy. Obesity. Treatment. Techniques. Review.

Recibido: 24/10/11.

Aceptado: 28/10/11.

Correspondence: Eduardo Espinet Coll. Unit of Endoscopy «Gastrodex». Instituto Universitario Dexeus. Gran Via Carles III, 71-75. 08028 Barcelona, Spain. e-mail: eespinet@idexeus.es
Espinet-Coll E, Nebreda-Durán J, Gómez-Valero JA, MuñozNavas M, Pujol-Gebelli J, Vila-Lolo C, Martínez-Gómez A, JuanCreix-Comamala A. Current endoscopic techniques in the treatment of obesity. Rev Esp Enferm Dig 2012; 104: 72-87.

\section{INTRODUCTION}

WHO (World Health Organization) defines obesity as an abnormal or excessive accumulation of body fat that can be detrimental to the health, with considerable associated morbidity and mortality (1). It is currently one of the main health problems in developed countries (2), with Spain reaching a prevalence of $15 \%$ among persons aged 25-64 years (3).

Although the degree of obesity can be quantified in different ways, the simplest and the easiest consist in calculating the body mass index (BMI, expressed in $\mathrm{kg} / \mathrm{m}^{2}$ ), to set an objective quantitative relationship (Table I).

There are different therapeutic strategies based on each obesity degree (4-6). In all cases it is essential the realization of an adequate dietary education, modification of lifestyle and physical activity. For the severely obese (type II) with associated diseases and the morbidly obese and superobese (types III-IV), these can assess surgical treatment in its various forms: restrictive techniques, malabsorptives or mixed. Whenever necessary, the treatment of any type of obesity can be complemented with pharmacotherapy and/or specialized psychological support.

According to the Fobi-Baltasar criteria $(7,8)$ that defines a good treatment of obesity, there is an agreement that the technique should be: safe (mortality $<1 \%$ and morbidity $<10 \%$ ), reproducible, offer a good quality of life, require few reviews ( $<2 \%$ per year), have minimal adverse effects and easily reversible. Its efficacy must be individually assessed, with the actual evidence that $>10-15 \%$ excess weight loss improves the health status and prevents or reduces the risk of cardiovascular and other obesity-related diseases. 


\section{ENDOSCOPIC THERAPIES}

During recent years have been developed and popularized some endoscopic treatments (non-surgical) aimed at patients with moderate-severe obesity in which medical therapy has failed or as its complement (9-14). These treatments can also be indicated in morbid patients when surgery is refused or contraindicated, when there is an excessive surgical risk or during the pre-operative period to reduce peri-operative complications (14-19) (Table II).

Each patient should be individually evaluated. For this reason, there are general and procedure-related contraindications to their use (Table III). In addition, all endoscopic procedures should be realized in specialized endoscopic units having expert surgical service to address potential complications.

In this article we will review the current state of the main endoscopic treatments of obesity (Table IV), in their restrictive and malabsorptive variants, paying special attention to the techniques that we have more experience with.

\section{INTRAGASTRIC BALLOON (IB)}

The idea of using an IB was carried out for the first time in 1982 from clinical observations with gastric bezoars (20), although after the initial series this technique had to be abandoned because of a prohibitive number of complications and premature balloon deflation rates. Among the first balloons, are the Garren-Edwards (1987), cylindrical elastomers filled with $250 \mathrm{cc}$ of air; those of Ballobes (1989), oval of elastomers filled with air $500 \mathrm{cc}$; those of Taylor (1990), oval silicone and with liquid $(500 \mathrm{cc})$; and those of WilsonCook (1990), oval of elastomer, inflated with air $300 \mathrm{cc}$.

Expert meetings (21) agreed that the ideal balloon design should meet the following requirements: a) smooth, durable material with low ulcerogenic and obstructive potential, b) incorporation of a radiopaque marker to allow appropriate follow-up in case of deflation; and c) possibility to adjust to a variety of sizes and fill it with fluid.

Table I. Obesity degrades

\begin{tabular}{|c|c|c|}
\hline$B M I\left(k g / m^{2}\right)$ & Category Who* & Category SEEDO** \\
\hline$<18.5$ & Underweight & Not enough weight \\
\hline $18.5-24.9$ & Normoweigt & Normoweight \\
\hline $25-26.9$ & Overweight & Grade I overweight \\
\hline $27-29.9$ & & $\begin{array}{l}\text { Grade II overweight } \\
\text { (preobesity) }\end{array}$ \\
\hline $30-34.9$ & Moderate obesity & Type I obesity \\
\hline $35-39.9$ & Severe obesity & Type II obesity \\
\hline $40-49.9$ & Morbid obesity & Type III obesity (morbid) \\
\hline $50-59.9$ & Superobesity & Type IV obesity (extrem) \\
\hline$>60$ & Super-superobesity & \\
\hline
\end{tabular}

* Degree of obesity according to the WHO. ** Degree of obesity according to the criteria established by the Spanish Society for Study of Obesity (SEEDO).
Table II. General indications for endoscopic treatment of obesity

\begin{tabular}{|c|c|}
\hline $\begin{array}{l}\text { Dependent on } \\
\text { the patient }\end{array}$ & $\begin{array}{l}\text { Age }>18 \text { years old (preferable 18-65 years) } \\
\text { Obesity refractory to dietetic treatment } \\
\text { Favourable assessment by Dietitian, } \\
\text { Endocrinology and Psychology } \\
\text { Understanding on the objectives of the } \\
\text { treatment and follow-up carried out }\end{array}$ \\
\hline $\begin{array}{l}\text { Dependent on } \\
\text { the degree of } \\
\text { obesity }\end{array}$ & $\begin{array}{l}\text { Moderate obesity (BMI 30-34.9) } \\
\text { Severe obesity (BMI 35-39.9) without } \\
\quad \text { associated diseases } \\
\text { Morbid obesity (BMI > 40) when: } \\
\text { - The patient refuses surgery } \\
\text { - There is a contraindication for surgery } \\
\text { - In the pre-operative period to reduce surgical } \\
\text { complications (especially in BMI > 50) }\end{array}$ \\
\hline $\begin{array}{l}\text { Dependent on } \\
\text { the experience } \\
\text { of the Centre }\end{array}$ & $\begin{array}{l}\text { Multidisciplinary Unit in treatment of obesity. } \\
\text { Clinical and technical expertise of each } \\
\text { endoscopic Unit }\end{array}$ \\
\hline
\end{tabular}

Physiologically, their restrictive effect increases the feeling of fullness, early satiety and slow gastric emptying, mainly during the first 3 months (22), in part associated with a possible decrease in plasma levels of ghrelin (23).

\section{Bioenterics intragastric balloon (BIB)}

In 1999 appeared the balloon of BioEnterics (BIB, Inamed Corporation, Arklow, County Wicklow, Ireland and Bioenterics Corporation, carpentry, California, USA), the most popular and commonly endoscopic device for weight loss used, and continuer to be until today (14). It consists of a silicone spherical balloon, very resistant to gastric acids, a smooth surface to reduce the gastric mucosa erosion risk, which is filled with isotonic saline and possesses a radiopaque self-sealing valve that allows a simple radiation location.

\section{Technique of BIB insertion (12, 24-26)}

The procedure can be done ambulatory, in the unit of endoscopy, under intravenous sedation and without the need for intubation. A conventional endoscopy dismisses contraindications (Table III). After removal of the endoscope, the deflated balloon is inserted into the gastric cavity by pushing in a tube. Connected to a $500 \mathrm{cc}(400-800 \mathrm{cc})$ bottle of saline solution-stained with $10 \mathrm{ml}$ of methylene blue (coloring allow detect potential losses) and, with endoscopic control, the balloon is slowly filled (about $13 \mathrm{~cm}$ in diameter), adjusting according to size and weight of the patient. 
Table III. General contraindications for the endoscopic treatment of obesity

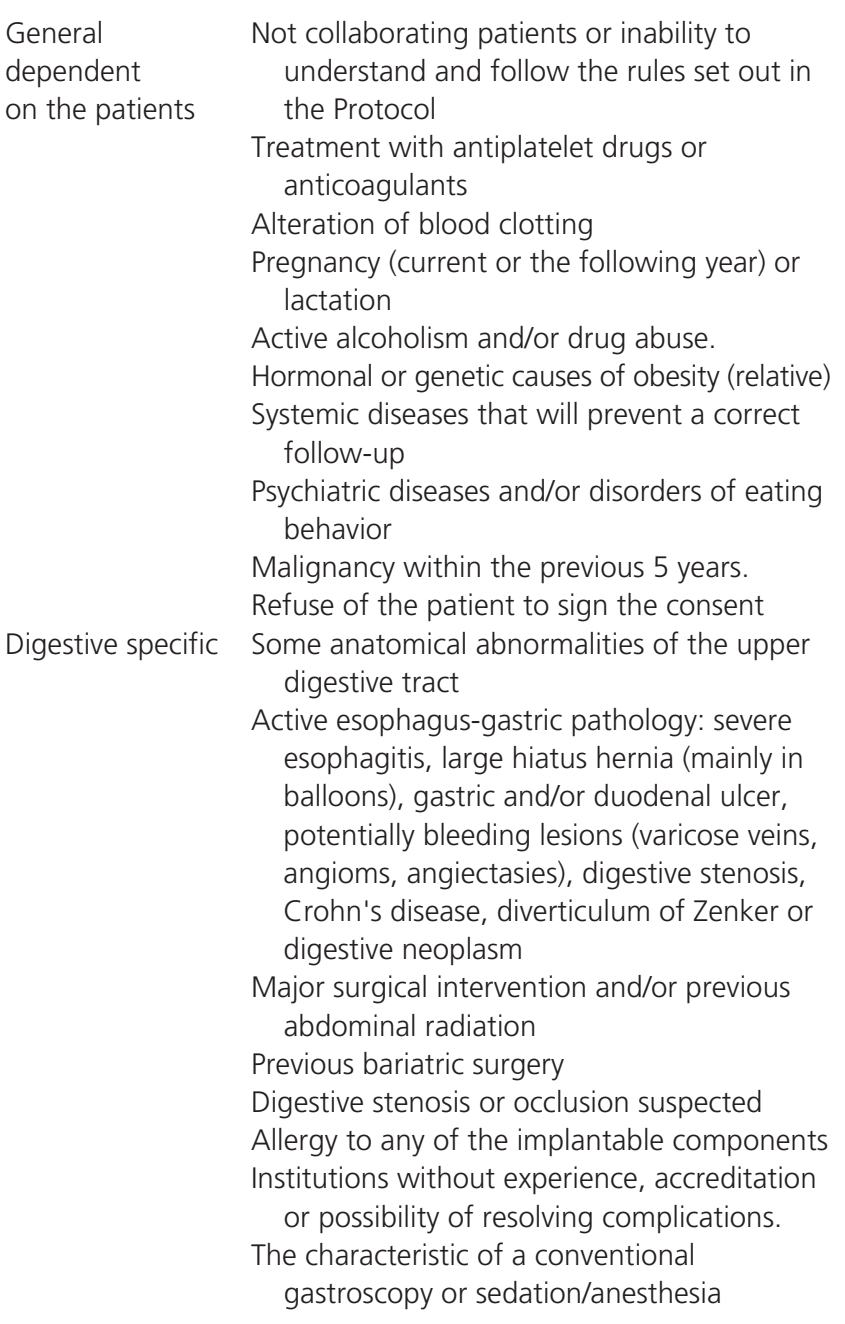

The infusion system is closed and creating the vacuum of the self-sealing valve. Gently pulling the balloon catheter (taking advantage of the resistance offered by the IEE or the distal tip of the endoscope), and is drawn through the mouth. Endoscopically the correct placement and the absence of leaks and complications must be confirmed. The mean time for positioning it is about 15 minutes (16) and it is important a doctor-nurse closely collaboration (26). The patient is monitored and after an hour can be discharged.

\section{Technique of BIB removal (12,24-26)}

After 6 months BIB must be removed, also under sedation (some medical centers use intubation). Secretions and the possible gastric residual food must be endoscopically vacuumed. Then a 2.3-lead diameter teflon needle is inserted (Wahlen, "Pauldrach Medical Innoflex" or similar) (27), the balloon is punctured and as much liquid as possible
Table IV. Main endoscopic possibilities in the treatment of obesity

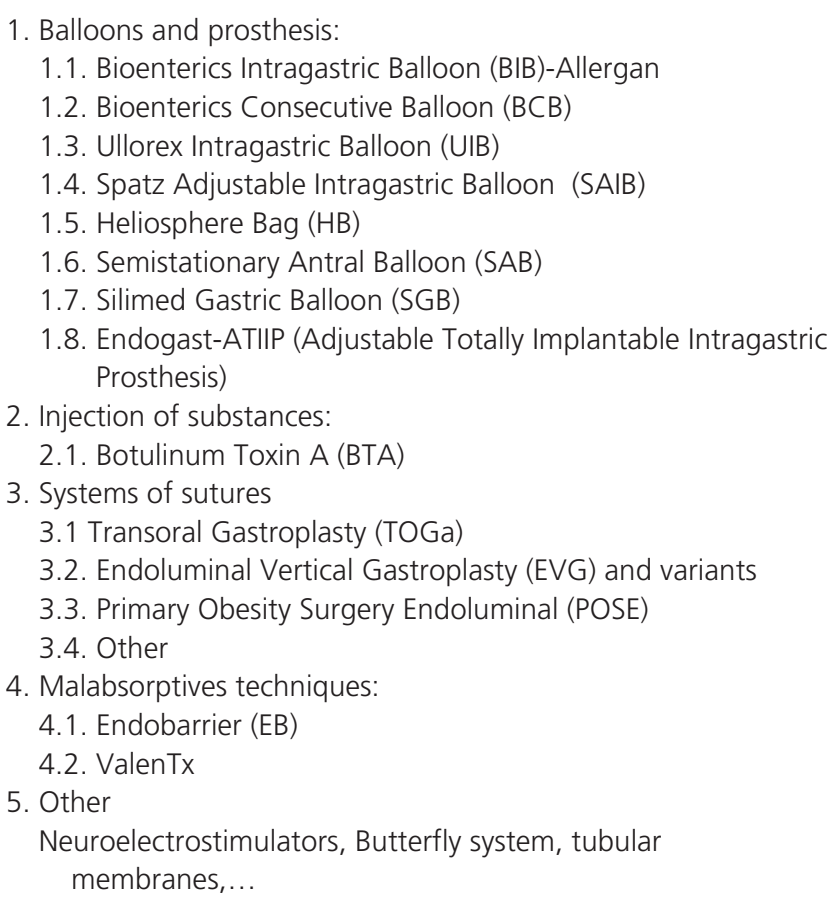

must be removed, so it is convenient to know the amount of fluid that was filled with. Then we grasp the balloon using a snare, a forceps or a clip of strange bodies (Wahlen serrated clamp for strange bodies or similar) (27), holding it preferably by the opposite side to the valve. We slowly remove the balloon until oral cavity with endoscopic control. We can facilitate the passing of the balloon through both esophageal sphincters with the administration of intravenous N-butyl bromide hyoscine (Buscapan $\left.{ }^{\circledR}\right)$. Then we endoscopically confirm the absence of complications. If there are no incidents, the patient may be discharged 30 minutes after extraction.

\section{Results of the BIB (Table V)}

The review by Dumonceau et al. (30 studies and 4,877 patients) (28) after the balloon removal, achieved a mean weight loss of $17.8 \mathrm{~kg}\left(4-9 \mathrm{~kg} / \mathrm{m}^{2}\right)$. In general, it ranges from $13-21 \mathrm{~kg}(29-30), 15.9$ and $17.8 \mathrm{~kg}$ in our series $(26,12)$, with a mean excess weight loss (EWL) of $18-51 \%$ $(11,18,25,29,31-36)$, of 38.3 and $45.4 \%$ in our studies $(26,12)$. It seems that the greater \% of EWL occurs in patients with lower BMI (31). Although there is great variability between subjects and studies, significant factors related to greater weight loss include initial BMI, patient's degree of motivation and adherence to the dietitian's program control $(12,26)$. The filled volume of the balloon does not seem to be clearly related to weight loss results (26). 
Table V. Effectiveness of the IB

\begin{tabular}{|c|c|c|c|c|}
\hline $\begin{array}{l}\text { Autor, year } \\
\text { No. balloons } \\
\text { (ref) }\end{array}$ & $\begin{array}{l}\text { Type of } \\
\text { ballon }\end{array}$ & Duration & $\begin{array}{l}\text { Mean } \\
\text { BMI } \\
\left(\mathrm{kg} / \mathrm{m}^{2}\right)\end{array}$ & $\begin{array}{l}\text { Weight } \\
\text { loss }\end{array}$ \\
\hline $\begin{array}{l}\text { Evans, } 2001 \\
\qquad n=63(18)\end{array}$ & BioEnterics & 7 months & 46.3 & $18.7 \%$ EWL \\
\hline $\begin{array}{l}\text { Loffredo, } 2001 \\
\qquad n=77 \text { (34) }\end{array}$ & BioEnterics & 6 months & 46.6 & $22.1 \% \mathrm{EWL}$ \\
\hline $\begin{array}{l}\text { Totté, } 2001 \\
n=69(32)\end{array}$ & BioEnterics & $\begin{array}{l}3 \text { months } \\
6 \text { months }\end{array}$ & & $\begin{array}{l}48 \% \text { EWL } \\
51 \% \text { EWL }\end{array}$ \\
\hline $\begin{array}{l}\text { Busetto, } 2004 \\
n=86(35)\end{array}$ & BioEnterics & 6 months & 58.4 & $26 \%$ EWL \\
\hline $\begin{array}{l}\text { Doldi, } 2004 \\
\qquad \mathrm{n}=349 \text { (9) }\end{array}$ & BioEnterics & 4 months & 42 & 4.8 BMI \\
\hline $\begin{array}{l}\text { Sallet, } 2004 \\
\quad n=323(33)\end{array}$ & BioEnterics & $\begin{array}{l}6 \text { months } \\
12 \text { months }\end{array}$ & 38.2 & $\begin{array}{l}48 \% \text { EWL } \\
51 \% \text { EWL }\end{array}$ \\
\hline Roman, 2004 & & & & \\
\hline $\begin{array}{c}n=176(11) \\
\text { Mathus, } 2005 \\
n=43(29)\end{array}$ & $\begin{array}{l}\text { BioEnterics } \\
\text { BioEnterics }\end{array}$ & $\begin{array}{l}4-6 \text { months } \\
12 \text { months } \\
24 \text { months }\end{array}$ & $\begin{array}{l}31 \\
43.3\end{array}$ & $\begin{array}{l}38.1 \% \mathrm{EWL} \\
21.3 \mathrm{~kg} \\
12.7 \mathrm{~kg}\end{array}$ \\
\hline $\begin{array}{l}\text { Genco, } 2005 \\
\quad n=2515(25)\end{array}$ & BioEnterics & 6 months & 44.4 & $33.9 \%$ EWL \\
\hline $\begin{array}{l}\text { Herve,2005 } \\
\quad n=100(31)\end{array}$ & BioEnterics & $\begin{array}{l}10 \text { months } \\
22 \text { months }\end{array}$ & 34 & $\begin{array}{l}40 \% \mathrm{EWL} \\
26.87 \% \mathrm{EWL}\end{array}$ \\
\hline $\begin{array}{l}\text { García, } 2006 \\
\quad n=31(26)\end{array}$ & BioEnterics & 6 months & 37.2 & $\begin{array}{l}38.3 \% \mathrm{EWL} \\
15.9 \mathrm{~kg}, 5.4 \mathrm{BMI}\end{array}$ \\
\hline $\begin{array}{l}\text { Espinet, } 2007 \\
n=25(12)\end{array}$ & BioEnterics & 6 months & 36.7 & $\begin{array}{l}45.4 \% \mathrm{EWL} \\
17.8 \mathrm{~kg}, 6.4 \mathrm{BMI}\end{array}$ \\
\hline $\begin{array}{c}\text { Escudero, } 2008 \\
n=38(36)\end{array}$ & BioEnterics & 6 months & 47.2 & $5.3 \mathrm{BMl}$ \\
\hline $\begin{array}{c}\text { Machytka, } 2011 \\
n=18(53)\end{array}$ & Spatz & $\begin{array}{l}6 \text { months } \\
12 \text { months }\end{array}$ & 37.3 & $\begin{array}{l}36.4 \% \text { EWL } 15.6 \mathrm{~kg} \\
48.8 \% \text { EWL } 24.4 \mathrm{~kg}\end{array}$ \\
\hline $\begin{array}{l}\text { Forestieri, } 2006 \\
n=10(54)\end{array}$ & $\begin{array}{l}\text { Heliosphere } \\
\text { Bag }\end{array}$ & 6 months & 43.3 & $\begin{array}{l}29 \% \mathrm{EWL} \\
17.5 \mathrm{~kg}, 5.9 \mathrm{BMl}\end{array}$ \\
\hline $\begin{array}{r}\text { Sciumè, } 2009 \\
n=50(56)\end{array}$ & $\begin{array}{l}\text { Heliosphere } \\
\text { Bag }\end{array}$ & 6 months & 39.8 & $5.9 \mathrm{BMl} 16.8 \mathrm{~kg}$ \\
\hline $\begin{array}{l}\text { Trande, } 2010 \\
n=17(57)\end{array}$ & $\begin{array}{l}\text { Heliosphere } \\
\text { Bag }\end{array}$ & 6 months & 46 & $5 \mathrm{BMl} 11 \mathrm{~kg}$ \\
\hline \multicolumn{5}{|c|}{ Lecumberri, 2011} \\
\hline $\mathrm{n}=82(58)$ & $\begin{array}{l}\text { Heliosphere } \\
\text { Bag }\end{array}$ & 6 months & 39.1 & $\begin{array}{l}33 \% \mathrm{EWL} 14.5 \mathrm{~kg}, \\
5.3 \mathrm{BMl}\end{array}$ \\
\hline
\end{tabular}

IB: intragastric balloon. BMI: body mass index. \%EWL: \% excess weight loss.

Although there are no evolutionary studies that assess long-term effectiveness, there is experience that \% noninsignificant of these patients can recover partial or total weight loss after the balloon is removed (28). However, in other patients these results are encouraging. Thus, Carbonelli et al. (10) describes that after extraction of the balloon the majority of patients have lost weight and some continue to lose it. Studies realized one year post-removal, EscuderoSanchís et al. (36) note that $48 \%$ of patients maintain or continue losing weight, Mathus-Vliegen and Tytgart (29) that $55 \%$ of patients had a sustained weight loss greater than $10 \%$ and Herve et al. (31) which remains a EWL of $26.8 \%$.

In superobesities, the BIB offers a EWL $>10 \%$ at 3 months (19), which some authors consider sufficient to diminish co-morbidities $(9,25,29)$, mainly diabetes $(9)$, obstructive sleep apnea syndrome (37) and liver volume (38), facilitating subsequent bariatric surgery.

In general, BIB can resolve about 52-100\% of co-morbidities (28). Genco et al. (25) detected $56 \%$ of obese patients with co-morbidities; after the balloon removals, $44.3 \%$ were resolved, $44.8 \%$ improved and $10.9 \%$ unchanged.

\section{Complications of the BIB}

In general it can be considered a safe and simple technique $(10,12,16)$, for both endoscopists and nurses (26), with an overall average rate of complications described that ranges between 2.8 and $40 \%(25,31,35-36)$.

- Clinical intolerances (Table VI): the most common symptoms are the presence of nausea, vomiting and upper abdomen pain (70-90\% of cases) for 3-7 days $(11,30-33,36)$, depending on the individual tolerability, the filled volume of the balloon and the preventive measures each patient follows. Although after this period tolerance is good at $>80 \%$ of cases (35), occasionally these inconveniences can remain for 3 weeks $(11-18 \%)(11,30)$, and may require hospital admission for a proper rehydration, having led to cases of transient hypokalemia (6-8\%) or kidney failure (1-4\%) $(11,30,36)$. Less frequently it may appear recurring abdominal pain (12-46\%) (11,30-31,33), GERDesophagitis $(1-11 \%)(11,12,25,26,29-30,36)$, bloating or constipation/diarrhea $(12,26)$. Other complications such as gastric ulcer and upper gastrointestinal bleeding $(11,25,30)$, regurgitation-aspiration (11) or tachyarrhythmia (39) have been described in rare cases. Some of them, if they are intense and persistent, can cause the early removal of the balloon in $1-2.5 \%$ $(25,28,36)$; it exists up to a $7-18 \%$ of global cases of clinical intolerance $(11,30,36)$.

- Technical complications (arising from balloon/ endoscopy) (Table VII):

- Related to the insertion/removal: it is, generally, a safe and simple technique. Isolated cases of acute gastric dilation (25) have been described in the insertion technique. During the extraction it may appear Mallory-Weiss laceration (29), a minor gastric bleeding caused of injury with a forceps (29) or esophagitis (11).

- Related to the permanence of the balloon: the most common complication is the deflated-rupture of the balloon, with rates ranging from $19-27 \%$ in some early series $(11,34)$ to a $0-4 \%$ in the latest $(9,18,25,29,30,33)$. This complication could produce their migration (11), with an spontaneous evacuation or a small intestine obstruction in a $0-4 \%$ $(11,18,25,29,33,40-42)$. Serum with methylene blue staining can detect early ruptures of the balloon. Less frequent complications $(0.2 \%)$, but serious, include gastric necrosis (43) and esophageal (44), gas- 
Table VI. Clinical intolerances of the IB

\begin{tabular}{|c|c|c|c|c|c|c|}
\hline $\begin{array}{l}\text { Author, year } \\
\text { No. balloons (ref) }\end{array}$ & Type of balloon & $\begin{array}{l}\text { Nausea and } \\
\text { vomiting }\end{array}$ & $\begin{array}{l}\text { Abdominal } \\
\text { pain }\end{array}$ & $\begin{array}{l}\text { GERD/ } \\
\text { esophagitis }\end{array}$ & $\begin{array}{l}\text { Peptic } \\
\text { ulcer }\end{array}$ & Other \\
\hline $\begin{array}{l}\text { Roman, } 2004 \\
\qquad n=176(11)\end{array}$ & BioEnterics & $\begin{array}{l}90 \%: 1 \text { week } \\
18 \%: 3 \text { weeks }\end{array}$ & $12.5 \%$ & $11.5 \%$ & 2 cases & $\begin{array}{l}8.5 \% \text { intol } \\
8.5 \% \text { : hipoK } \\
1.1 \% \text { : KF } \\
1 \text { aspiration }\end{array}$ \\
\hline $\begin{array}{l}\text { Mathus, } 2005 \\
n=43(29)\end{array}$ & BioEnterics & $6.9 \%$ & & $7 \%$ & & $7 \%$ intol \\
\hline $\begin{array}{c}\text { Al-Momen, } 2005 \\
n=44(30)\end{array}$ & BioEnterics & $\begin{array}{l}77 \%: 1 \text { week } \\
11 \%: 3 \text { weeks }\end{array}$ & $15.9 \%$ & $6.8 \%$ & 1 case & $\begin{array}{l}6.8 \%: \text { hipoK } \\
4.5 \%: \mathrm{KF} \\
4 \text { intol }\end{array}$ \\
\hline $\begin{array}{l}\text { Herve, } 2005 \\
\qquad n=100(31)\end{array}$ & BioEnterics & $\begin{array}{l}78 \% \text { nausea } \\
66 \% \text { vomiting }\end{array}$ & $46 \%$ & & & \\
\hline $\begin{array}{l}\text { García, } 2006 \\
\qquad n=31(26)\end{array}$ & BioEnterics & 13\%: 1 week & & $6.5 \%$ & 0 & $\begin{array}{l}25 \% \text { : none } \\
45 \% \text { : constip. } \\
29 \% \text { : aerophagy }\end{array}$ \\
\hline $\begin{array}{l}\text { Espinet, } 2007 \\
\qquad n=25(12)\end{array}$ & BioEnterics & 25\%: 1 week & & $8.3 \%$ & 0 & $\begin{array}{l}33 \% \text { : none } \\
41 \% \text { : constip. } \\
37 \% \text { : aerophagy }\end{array}$ \\
\hline $\begin{array}{c}\text { Escudero, } 2008 \\
n=38\end{array}$ & BioEnterics & $\begin{array}{l}71 \% \text { nausea } \\
57 \% \text { vomiting }\end{array}$ & & 2 cases & & $\begin{array}{l}4 \text { intol } \\
\text { HipoK } \\
\text { KF }\end{array}$ \\
\hline $\begin{array}{c}\text { Machytka, } 2011 \\
n=18(53)\end{array}$ & Spatz & $\begin{array}{l}\text { 100\%: } 1 \text { week } \\
-33 \% \text { mild } \\
-33 \% \text { moderate } \\
-33 \% \text { severe }\end{array}$ & 100\%: 1 week & & $\begin{array}{l}2 \text { cases } \\
(1 \mathrm{SE})\end{array}$ & $\begin{array}{l}1 \mathrm{M}-\mathrm{W} \\
\text { Improved to decrease } \\
\text { the volume }\end{array}$ \\
\hline $\begin{array}{c}\text { Nebreda, } 2011 \\
n=107\end{array}$ & Spatz & 12 cases & 12 cases & & $\begin{array}{l}5 \text { cases } \\
(1 \mathrm{SE})\end{array}$ & $1 \mathrm{M}-\mathrm{W}$ \\
\hline $\begin{array}{c}\text { Forestieri, } 2006 \\
n=10(54)\end{array}$ & Heliosphere Bag & & & & & Generalized discomfort \\
\hline $\begin{array}{l}\text { Sciumè, } 2009 \\
n=50(56)\end{array}$ & Heliosphere Bag & Dyspepsia x2 days & & & & $\begin{array}{l}2(4 \%) \text { extraction in } \\
24 \mathrm{~h} \text { by acute intolerance } \\
\text { Exc tol }\end{array}$ \\
\hline $\begin{array}{l}\text { Trande, } 2010 \\
n=17(57)\end{array}$ & Heliosphere Bag & Dyspepsia x3 days & & & 1 case & $\begin{array}{l}1 \mathrm{Cl} \\
\text { Exc tol }\end{array}$ \\
\hline $\begin{array}{c}\text { De Castro, } 2010 \\
n=18(55)\end{array}$ & Heliosphere Bag & & & & & $\begin{array}{l}\text { Good } \\
(=\text { that BIB })\end{array}$ \\
\hline
\end{tabular}

Lecumberri, $2011 \quad$ Heliosphere Bag 7.4\% first week

$$
\mathrm{n}=82(58)
$$

IB: intragastric balloon. Intol: digestive intolerance. HypoK: hypokalemia. KF: kidney failure. M-W: Mallory-Weiss. SE: surgical extraction. Exc tol: excellent tolerance. Cl: cardiac infarction. BIB: bioenterics intragastric balloon.

tric $(25,30,32,36,45,46)$ or intestinal (42) perforations, which require urgent surgical interventions $(11,25$, $42,46)$. Even isolated cases of death after some severe complications have been described $(25,30,36,47,48)$.
In our experience, documented in two series of 31 and 25 BIBs $(12,26)$, a case of major nosebleed which impeded the placement of the balloon occurred. However, it did not run any complication for the balloon or the endoscopic tech- 
nique. Global tolerance in our two series was, respectively, excellent in the 96.5 and $62 \%$, bad in the 3.2 and $0 \%$ and acceptable in the other cases.

\section{Satisfaction of the patients with BIB}

The global final degree of acceptance is good (80\%) (34). According to Totté et al. (32), $15 \%$ were very satisfied, $13 \%$ satisfied, $22 \%$ reasonably satisfied, $9 \%$ poorly satisfied and $40 \%$ totally dissatisfied of the weight loss. In our results $(12,26)$ the overall satisfaction was excellent in $50 \%$ $37.6 \%$, good in and $33.3 \%$, regular in 20 and $20.8 \%$ and poor in $0 \%$ and $8.3 \%$ of the cases respectively.

\section{Bioenterics consecutive balloon}

After the removal of the balloon, it is feasible to place a second balloon for 6 months more without any difficulty. It seems to be sure and well tolerated, with persistence of weight loss but with lower results to those obtained after the first balloon $(49,50)$.

\section{Ullorex balloon}

The Ullorex balloon (Phagia Technologies, Inc., USA) is a large capsule that is injected with citric acid and swallowed without endoscopy, been inflated in the stomach $(300$ $\mathrm{cm}^{3}$ ) in about 4 minutes. After 30 days, gastric acid degrades a plug on the balloon, it deflates and it is excreted in feces. The technique seems successful, though the results are very short-term and more consistent studies are required (51). The importance of endoscopy is to detect and solve potential complications of the device.

A variant in research is the polymer pill, developed by BaroNova (BaroNova Therapeutics Inc., Foster City, California). A pill that after its intake is expanded in your stomach for a week and is degraded as it passes through the intestinal tract. In theory, it could be taken when controlled at regular intervals of time (52).

\section{Spatz adjustable intragastric balloon (SAIB)}

In recent years various alternatives treatments to the intragastric balloon of Bioenterics have been proposed. One of them is the Spatz Adjustable Intragastric Balloon (Spatz GFAR, Inc., NY, USA) with 3 major components:

- The balloon: spherical and made of silicone.

- An anchor: covered with silicone and with an internal network, to facilitate the insertion and the removal of the balloon and with an attached migration prevention.

- A filling tube: made of silicone, shrink and stretch, that allows to modify the fluid volume of the balloon.

There is a limited clinical experience, so we will base our study on the manufacturer indications, the first and unique preliminary study published by Machytka et al. (53) and our own endoscopic experience in 107 SAIB.

\section{Technique of insertion}

It differs not in excess of the annotated with the BIB, with the advantage that it possesses the anchor which allows, theoretically, to straighten it to implant it with minor technical problems. Implantation average time ranged from 8 to 15 minutes (53). The first cases were filled with saline $400 \mathrm{cc}$, under sedation and ambulatory (53).

\section{Adjustment of the SAIB}

The SAIB is the first adjustable gastric balloon because the filling tube allows to reduce the volume of the balloon if the patient has intolerance (nausea, abdominal pain,...) or fill it increasing its volume if the patient regains appetite or weight loss stops (at 6 months in our series). This allows a greater and more sustained weight loss and a 1 year treatment. The balloon adjustment procedure is simple, it lasts about $15 \mathrm{~min}$ utes and it is performed by extracting, exclusively and under endoscopic control, the filling tube without having to extract the balloon of the stomach. Machytka et al. performed 16 adjustments: 6 of them to alleviate intolerances $(117 \mathrm{~mL}$ evacuated) and 10 to increase weight loss (188 $\mathrm{mL}$ added).

\section{Technique of removal}

The system has the chain inside the anchor and the valve outside the balloon; after its discharge, theoretically its removal should be easier (and it can be performed with a standard polypectomy snare) (53). However, its size and external irregular morphology cause that in its habitual practice it becomes more laborious than the BIB procedure.

\section{Results (Table V)}

Machytka et al. (53) treated 18 patients with an initial mean BMI of $37.3 \mathrm{~kg} / \mathrm{m}^{2}$. Mean weight loss at 24 and 52 weeks was of 15.6 and $24.4 \mathrm{~kg}$ (EWL of 36.4 and $48.8 \%$ respectively), being greater in those patients who followed strict controls, with improvement or stability of comorbidities (hypertension and diabetes). Patients safely continue to lose weight beyond 6 months.

\section{Complications (Tables VI and VII)}

- Study of Machytka et al. (53): nausea, vomiting and abdominal pain at the first week in $100 \%$ of cases 
Table VII. Complications of the IB

\begin{tabular}{|c|c|c|c|c|c|c|}
\hline $\begin{array}{l}\text { Author, year } \\
\text { No. balloons (ref) }\end{array}$ & Type of balloon & $\begin{array}{l}\text { Deflation/ } \\
\text { rupture }\end{array}$ & $\begin{array}{l}\text { Migration/ } \\
\text { obstruction }\end{array}$ & $\begin{array}{l}\text { Early } \\
\text { removal }\end{array}$ & $\begin{array}{l}\text { Insertion/extraction } \\
\text { problems }\end{array}$ & Other \\
\hline $\begin{array}{l}\text { Evans, } 2001 \\
\qquad n=63(18)\end{array}$ & BioEnterics & 3 cases $(2.3 \%)$ & 3 cases $(4,7 \%)$ & & & \\
\hline $\begin{array}{l}\text { Loffredo, } 2001 \\
\qquad n=77 \text { (34) }\end{array}$ & BioEnterics & 15 cases $(19 \%)$ & & & & \\
\hline $\begin{array}{l}\text { Sallet, } 2004 \\
\quad n=323(33)\end{array}$ & BioEnterics & 1 case & 3 cases $(1 \%)$ & & & \\
\hline $\begin{array}{l}\text { Roman, } 2004 \\
n=176(11)\end{array}$ & BioEnterics & $27,8 \%$ & $\begin{array}{l}50 \text { migration cases } \\
(1 \mathrm{SE})\end{array}$ & $\begin{array}{c}1 \text { esophagitis } \\
\text { during the } \\
\text { extraction }\end{array}$ & & 49 cases of SPE \\
\hline $\begin{array}{c}\text { Al-Momen, } 2005 \\
n=44(30)\end{array}$ & BioEnterics & 0 & & & & $\begin{array}{l}1 \mathrm{GP} \\
1 \text { deaht by } \\
\text { other causes }\end{array}$ \\
\hline $\begin{array}{l}\text { Genco, } 2005 \\
\quad n=2,515(25)\end{array}$ & BioEnterics & $0.36 \%$ & $0.76 \%$ & $1.12 \%$ & $0,08 \%(A G D)$ & $\begin{array}{l}0.19 \% \text { GP } \\
2 \text { surgeries } \\
2 \text { deahts }\end{array}$ \\
\hline $\begin{array}{l}\text { García, } 2006 \\
\qquad n=31(26)\end{array}$ & BioEnterics & 0 & 0 & 0 & 1 bleeding & $96.8 \%$ none \\
\hline $\begin{array}{l}\text { Nebreda, } 2011 \\
\quad \mathrm{n}=107\end{array}$ & Spatz & & $\begin{array}{l}7 \text { (6.5\%) } \\
\text { duodenal } \\
\text { mechanism }\end{array}$ & $12(11.2 \%)$ & $\begin{array}{l}1 \mathrm{M}-\mathrm{W} \\
4 \text { leeks to } \\
\quad \text { fill it }\end{array}$ & $1 \mathrm{SE}$ \\
\hline $\begin{array}{c}\text { Forestieri, } 2006 \\
n=10(54)\end{array}$ & Heliosphere Bag & 3 cases & 1 case & & $\begin{array}{l}5 \text { judgement } \\
\text { in implante system }\end{array}$ & $\begin{array}{l}\text { Difficulty in } \\
\text { implant }\end{array}$ \\
\hline $\begin{array}{l}\text { Sciumè, } 2009 \\
n=50(56)\end{array}$ & Heliosphere Bag & 2 cases $(4 \%)$ & & $\begin{array}{l}8 \%(4): \\
2 \text { intol } \\
2 \text { desinfl }\end{array}$ & & \\
\hline $\begin{array}{l}\text { Trande, } 2010 \\
n=17(57)\end{array}$ & Heliosphere Bag & $\begin{array}{l}1 \text { case } \\
\text { (SE) }\end{array}$ & 1 case & & & $\begin{array}{l}\text { Extraction } \\
\text { problems }\end{array}$ \\
\hline $\begin{array}{c}\text { De Castro, } 2010 \\
n=18(55)\end{array}$ & Heliosphere Bag & & 2 cases & 4 cases & & 4 ERD or SE \\
\hline $\begin{array}{l}\text { Lecumberri, } 2011 \\
\quad n=82 \text { (58) }\end{array}$ & Heliosphere Bag & 2 cases $(3 \%)$ & & & & $1(1.2 \%)$ SE \\
\hline
\end{tabular}


(mild $1 / 3$, moderate $1 / 3$, severe $1 / 3$ ), improved after adjusting the volume. Seven balloons (39\%) were removed prematurely: one valve malfunction of deflation mechanism, one erosive gastritis, one MalloryWeiss tear, one gastric perforating ulcer by the intake of NSAIDs (which required surgical intervention), one balloon deflation and two incidents of catheter shear from the chain (one asymptomatic and the other one with an esophageal laceration, but without perforation, during the extraction). Although the mechanism of anchor ( $7 \mathrm{~cm}$ diameter) theoretically provides greater security and prevents the balloon to migrate in one alleged case of deflated, 4 migration of the distal catheter into the duodenum were appreciated, $3 / 5$ with the first-generation SAIB and only 1/13 with the second-generation SAIB, being able to relocate endoscopically. There were no cases of gastrointestinal bleeding, distal migration or deaths.

- In our experience in 107 SAIB, we proved 1 Mallory-Weiss self-limited during the placement and other 16 relevant incidents $(15 \%)$ :

- 4 leak to fill it (requiring removal of the balloon and replacement by another).

- 12 early removal by intolerance (vomiting and persistent abdominal pain):

- 7 (6.5\%) of them by the anchor migration into the duodenum, showing 2 duodenal ulcer (one required surgical treatment), 1 antral ulcer and 1 erosive gastritis.

- 1 gastric-fundus ulcer by decubitus.

- 4 clinical intolerances.

In our opinion and due to the number of evident complications, we believe that the device requires improvements and some technical and design modifications that provide greater security and better tolerance.

\section{Air intragastric balloon-Heliosphere Bag (HB)}

In order to try to improve the tolerance of existing intragastric balloons, a new spherical balloon similar to the BIB made of silicone but inflated with air $\left(800-1000 \mathrm{~cm}^{3}\right)$ was developed in 2004: the Heliosphere Bag (Helioscopie Medical Implants, Vienne, France) (54).

\section{Results (Table V)}

The HB showed an acceptable profile of efficacy in weight loss in all cases after 6 months $(54,56,58)$, similar to that obtained with the BIB (55).

\section{Technique}

The first published cases $(54,55)$ presented a large number of instrumental and technical problems; it seems the first ones can be resolved after a learning curve of 10 procedures (56) and the latter should be improved with modifications of the device design.

Although some authors argue that this is a safe and easy technique $(56,58)$, others point out an excess of technical problems (55), mainly in its extraction (57) or in the design of the balloon (54).

\section{Tolerance and complications (Tables VI and VII)}

In the first series the balloon produced general discomfort in most of patients (54), but subsequent tolerance was good/excellent in most publications $(56,57)$, showing exclusively characteristic gastric symptoms for the first week (56-58), requiring up to a $4 \%$ of early removal at $24 \mathrm{~h}$ by acute intolerance (54). According to De Castro et al. (55), tolerance of the HB is similar to that observed in the BIB.

There is a $3-4 \%$ of spontaneous deflated $(56,58)[30 \%$ in the first series (54)], 5-11\% of migrations $(54,55,57)$ and isolated cases of balloon rupture (57), requiring surgical removal in $1.2-22 \%$ of cases $(55,57,58)$.

Although this technique is still difficult to assess because of its limited clinical experience (14), efficacy and tolerance appears to be equivalent to BIB, probably with a more difficult extraction procedure and slightly higher its incidence of deflated with undetectable migrations.

\section{Semistationary antral balloon (SAB)}

The SAB (JP Industria Farmacéutica S.A., Brazil) is a pear-shaped device, filled with saline $(150-180 \mathrm{ml})$, and with a $30 \mathrm{~cm}$ silicone duodenal stem for anchoring in the antrum with its conical pole oriented to the pylorus and a 7-g metallic counterweight at tip. Its theoretical mechanism is the intermittent occlusion of the pyloric opening, prolonging gastric emptying and stimulating antroduodenal satiety receptors. A first study in 26 patients (59) showed a EWL of $12.1 \%$ at 6 months, confirmed as safe and well tolerated, though spontaneous deflated complications ( $\mathrm{n}=$ 4) with migration and small bowel obstruction were appreciated in 1 case. The procedure still needs technical improvements to universalize it $(14,59)$.

\section{Silimed gastric balloon (SGB)}

The Silimed Company (Silimed Brazil) has designed a spherical transparent balloon made of silicone coated with a self-sealing valve that is filled with $650 \mathrm{ml}$ of saline. It is characterized by being advanced by scope traction under direct visualization, rolled up inside a thin silicone sheath anchored to the tip of the endoscope with a snare. It's removed as an entire system held in an overtube. The procedure is short on time ( 9 minutes the placement and 13 minutes the extraction) (60) and safe, but with some com- 
plications (21\% of early removals and $3.8 \%$ of spontaneous deflations), with a mean weight excess loss after the 6months treatment of $10.4 \mathrm{~kg}$ and $3.9 \mathrm{BMI}(60)$. However, randomized trials are required to prove the suggested benefits.

\section{Endogast-ATIIP}

The Adjustable Totally Implantable Intragastric Prosthesis (Endogast-ATIIP, Districlass Medical S.A., France) consists of an air-filled oval polyurethane prosthesis (210$300 \mathrm{ml}$ ) (61) inserted with a combined endoscopic-surgical procedure in the gastric corpus-fundus area using a method similar to the percutaneous endoscopic gastrostomy technique (PEG) and connected to a subcutaneous completely implantable system (fixing the stomach to the abdominal wall) which avoids dislocations and allows adjustment of the volume of the balloon. Although the method requires further and larger studies, it could be indicated particularly in patients over 60 years old with morbid and extremely obesity (61).

\section{Results}

Preliminary studies show mean weight loss rates of 8.4 and $12.2 \mathrm{~kg}$ (28.7 and $39.2 \%$ of EWL) at 6 and 12 months, respectively (61).

\section{Complications}

It seems to be a feasible, reproducible and well tolerated procedure (61), although there have been stated some early complications (symptomatic pneumoperitoneum in 5.2\% or subcutaneous local infection in 12\%) or late complications (port erosion in 5.2\%) and other more severe as those associated with the PEG and the method of insertion (14).

\section{INTRAGASTRIC INJECTION OF BOTULINUM TOXIN}

The botulinum toxin type A (BTA) inhibits acetylcholine release at the neuromuscular junction, with its subsequent local muscle paralysis. Its gastric injection can, theoretically, produce an inhibition of antral peristalsis inducing a delay in gastric emptying, determining early satiety and weight loss.

\section{Technique}

Under endoscopic or EUS-guided control (62), intramuscular gastric antrum 100 to 500 U BTA is administrated, in a number of punctures that ranges from 8 to 24 in circular disposition. Other authors inject BTA into both antral and gastric fundus regions $(63,64)$.

\section{Results (Table VIII)}

This idea, reinforced by Rollnik et al. in 2003 (65), was developed from 2005, although offering different results. Six studies have been published between 2005 and 2007 $(64,66,70)$ and only in one of them a beneficial effect of BTA on weight loss has been observed (64). More recent studies show a decrease in 4-5 BMI $(62,63)$, with increased early satiety and gastric emptying time and decreased gastric maximum capacity, with better results in the proceedings in which given BTA both in antrum and fundus than in those administered only in antrum $(63,64)$.

The results do not seem to depend on the dosage of administered TBA $(64,66,68)$, although according to Topazian et al. (62) the administration of $300 \mathrm{U}$ seems to be better than $100 \mathrm{U}$. It has not been observed a completely direct relationship between the number of injections (from 8 to 24), its depth and the antro-pyloric area administered (64). However, although it seems a reproducible technique, its effectiveness is limited and transient with a 3-6 months duration.

\section{Tolerance (Table VIII)}

All documented series coincide in stating that it is safe, well tolerated treatment without significant side effects, both gastric and neuromuscular (71), regardless of dose and gastric place of BTA administration $(62,64,66-68,72)$.

\section{SYSTEMS OF SUTURES}

\section{TOGa}

The TOGa system (TransOral Gastroplasty, Satiety Inc., Palo Alto, CA) is the first endoscopic device created to imitate the gastric restrictive surgery, designed to be less invasive, with less complications and with a faster recovery.

\section{Technique}

We endoscopically insert a $18 \mathrm{~mm}$ metal device in the stomach. With a set of guided staplers, we create a stapled restrictive pouch along the lesser gastric curvature. The output of the pouch is pressed through a second device, so the amount of intake that the patient can tolerate in one shot is limited. The gastroplasty is fashioned as an 8-cm long tube from the gastro-esophageal junction and, with its restriction, the new created sleeves length diameter decreases from 20 to $12 \mathrm{~mm}$. The procedure lasts about 2 hours. At 3 months, re-treatment consisting in additional distal restrictions can be done, if necessary $(73,74)$. 
Table VIII. Main features of endoscopic treatment with Botulinum Toxin A (BTA)

\begin{tabular}{|c|c|c|c|c|c|c|c|}
\hline $\begin{array}{l}\text { Author, year } \\
\text { No. cases (ref) }\end{array}$ & Place & $\begin{array}{l}\text { Number } \\
\text { (U-TBA) }\end{array}$ & Duration & Tol & SEF & Efficacy & Other \\
\hline $\begin{array}{l}\text { García-Compean, } \\
\quad \begin{array}{l}2005 \\
n=12(70)\end{array}\end{array}$ & Antrum & $100 \mathrm{U}$ & 4 and 8 weeks & Good & No & No & $\begin{array}{l}\text { No changes in WL } \\
\text { nor GE }\end{array}$ \\
\hline $\begin{array}{l}\text { Albani, } 2005 \\
\qquad n=8(68)\end{array}$ & Antrum & $500 \mathrm{U}$ & & Good & No & $\begin{array}{l}\text { No } \\
\text { (variable) }\end{array}$ & \\
\hline $\begin{array}{l}\text { Júnior, } 2006 \\
\qquad n=12(67)\end{array}$ & Antrum & $\begin{array}{l}200 \cup v s . \\
300 \cup\end{array}$ & 12 weeks & Good & No & No & $\begin{array}{l}\text { All ES } \\
\text { WL: } 200=300 \\
\text { GE: } 200=300\end{array}$ \\
\hline $\begin{array}{l}\text { Mittermair, } 2007 \\
n=10(66)\end{array}$ & $\begin{array}{l}\text { Antrum and } \\
\text { distal body }\end{array}$ & $200 \mathrm{U}$ & 6 months & Good & No & No & $\begin{array}{l}\text { No WL } \\
\text { No ES }\end{array}$ \\
\hline $\begin{array}{l}\text { Foschi, } 2008 \\
\qquad n=30(63)\end{array}$ & $\begin{array}{l}\text { Antrum } \\
\text { fundus }\end{array}$ & $\begin{array}{l}120 U \\
80 U\end{array}$ & 2 months & Good & No & $\begin{array}{l}-11.8 \mathrm{~kg} \\
-4.1 \mathrm{BMI}\end{array}$ & \\
\hline $\begin{array}{l}\text { Topazian, } 2008 \\
n=10(62)\end{array}$ & $\begin{array}{l}\text { Antrum } \\
\text { (EUS) }\end{array}$ & $\begin{array}{l}100 \mathrm{U} \\
\text { VS. } \\
300 \mathrm{U}\end{array}$ & $\begin{array}{l}16 \text { weeks } \\
16 \text { weeks }\end{array}$ & $\begin{array}{l}\text { Good } \\
\text { Good }\end{array}$ & $\begin{array}{l}\text { No } \\
\text { No }\end{array}$ & - $4.9 \mathrm{BMI}$ & $\begin{array}{l}\uparrow \text { Saciety } \\
\text { Good WL } \\
\downarrow \text { GE }\end{array}$ \\
\hline
\end{tabular}

U-TBA: units of toxin botulinum A. Tol: tolerance. SEF: side effects. WL: weight loss. GE: gastric emptying. ES: early satiety. GET: gastric emptying time. GC: gastric capacity. BMI: body mass index. EUS: endoscopic ultrasonography.

\section{Results}

Early studies (73) showed a mean excess weight loss of 22.6 and $24.4 \%$ at 3 and 6 months respectively. With the second device generation (74) they have improved their results in weight loss $(24.0 \mathrm{~kg}, 8.5 \mathrm{IMC}$, and $46.0 \%$ of excess weight loss at 6 months), also in parameters of quality of life and in insulin resistance with a consequent reduction in its secretion (75).

\section{Tolerance}

There were no serious adverse effects (73-75), except for nausea, vomiting, abdominal pain and transient dysphagia during the first 5 days.

\section{Safety}

Early experience indicates that sutures are completely safe in all patients $(74,75)$. At 6 months post-treatment, all patients had persistent full or partial stapled sleeve, with evident gaps in the staple line in $13 / 21$ patients. Although the system is not reversible, in those patients with unsatisfactory results on weight loss, the performance of TOGa does not increase the difficulty nor the risk of a subsequent laparoscopic gastric bypass conversion (76).

\section{Endoluminal vertical gastroplasty (EVG)}

Since the initial experience offered by the EndoCinch device for the treatment of GERD, several endoscopic suturing devices and vertical gastroplasty machines have been developed, initially with the Endoscopic Sewing Machine design (C.R. Bard Inc., Murray Hill, New Jersey, USA) (77-79).

Fogel et al. (80) first described the use of the Bard EndoCinch Suturing System (C.R. Bard, Inc., Murray Hill, New Jersey). Seven sutures were deployed in a continuous and cross-linked fashion from the proximal fundus to the distal body, which limited gastric distention. The simple procedure was completed in approximately 45 minutes, discharging the patient at the same day. The study in 64 patients followed up for 12 months exhibited a high efficacy (significantly higher percent excess weight loss of $58.1 \%$, decreasing BMI from 39.9 to $30.6 \mathrm{~kg} / \mathrm{m}^{2}$ ) and safety (absence of serious adverse effects).

A new generation of endoscopy suturing device is the TRIM procedure, a transoral method of gastric volume reduction using the RSS (Restore Suturing System): 4-8 plications are placed to approximate the anterior and posterior gastric walls to achieve restriction of the upper stomach. The average procedure time is 125 minutes. The first study in 18 patients seems to be safe, well tolerated and without serious complications. Only the typical nausea, vomiting and abdominal discomfort in the early hours are 
observed (81), but only with a relative efficacy in the long term by reopening the restricted gastric volume.

Subsequently other experimental gastric partitioning procedures in animal models, as the Eagle Claw (Olympus Corporation, Tokyo, Japan) have been described. It has been improved with the Eagle Claw VII (Apollo Group and Olympus Corporation), in which Hu et al. (78) have practiced a longest plication which could influence a larger gastric restriction $(30 \mathrm{cc})$, similar to that obtained using surgical technique (79). More studies are needed to assess the efficacy, safety and their reproducibility in the long term.

\section{POSE}

Currently some medical centers are practicing the new technique of the POSE (Primary Obesity Surgery Endoluminal), consisting on a simple restrictive endoscopic method based on performing and suturing (plicating) gastric folds mainly in fundus (also in antrum), aimed to reduce the size and limit the capacity of the stomach and producing early satiety sensation.

Although its experience is limited, the system is designed to stay in place for life. However, its reversibility is allowed. It seems to be a relatively simple, safe and outpatient procedure, which lasts about 60 minutes. The initial expectation indicated an estimated effectiveness that could reach up to $45 \%$ of excess weight loss.

\section{Other suture techniques}

The SafeStitch device (SafeStitch Medical Inc., Miami, Florida), the Medical Power system (Power Medical Interventions, Inc., Langhorne, Pennsylvania) or the Endoscopic Suturing Device (Wilson-Cook Medical, Winston-Salem, North Carolina) are some of the innovative research suture systems.

\section{MALABSORPTION TECHNIQUES}

\section{Endobarrier}

The endoscopic procedure of the Endobarrier (GI Dynamics, Inc., Watertown, Mass) is the first strictly endoluminal malabsorptive device designed to create an endoscopic duodenal-jejunal by-pass; as well as providing weight loss, it could be a valid option to take control over the diabetes mellitus (DM) (82-83).

\section{Mechanism}

The Endobarrier is an intraluminal liner looking like a thin, flexible and tube-shaped liner, anchored in the bulb as a self-expanding metallic prosthesis and fits inside the duodenum to proximal jejunum $(60 \mathrm{~cm})$, creating a "internal barrier" ("Endo-Barrier") between a portion of the intestinal wall and ingested food, with an effect similar to the surgical gastric bypass. Thus, chyme passes through the pylorus to the interior of the Endobarrier and anterogradly moves by intestinal peristalses, while the bile and pancreatic enzymes pass out of the sleeve and are mixed with chime in the jejunum, at the end of the device (82).

This treatment should be offered in referred centers with a wide experience in obesity and diabetes diseases that must have a Multidisciplinary Unit with Dietitian, Endocrinology, Diabethology and Psychology, with experienced and specifically trained endoscopist in the technique and surgery service availability.

\section{Indications and contraindications}

The main indication is in obese patients that have diabetes (especially type I moderate obesity with type 2 diabetes with plasma glucose level of difficult control) (82). Other possible options include morbid obesity with surgical contraindication or prior to surgery to ensure its effectiveness or decrease per-operatories complications $(83,86)$. All of these can join the DM in adults. In the future, it would be interesting to see whether this technique could also be used in early stages of the disease, as a substitute or as a complement to drug treatment. In general, the indications are basically those noted in table II, with the added value associated with the adult DM.

According to our experience in endoscopy of obesity and in the specific technique of the Endobarrier in animal models and according to the review of the limited literature, we believe that the criteria for contraindication are to conform to those described in table III.

\section{Endoscopic technique}

The technique of the Endobarrier is made exclusively by transoral endoscopy. It is not a very difficult procedure but relatively laborious and protocolarious, so it is recommended to be carried out by two specifically trained endoscopists and in reference centers with experience in endoscopic-fluoroscopic mixed therapy.

\section{Introduction of the device}

Although the first cases have been practiced in the operating room and with the patient hospitalized for 24 hours, the procedure is designed to be ambulatory and carried in endoscopy units.

Five successive protocol stages are required with learning and close collaboration between the two endoscopists, with a mean implant time of 26-35 minutes $(85,87)$. 
Table IX. Effectiveness of the Endobarrier

\begin{tabular}{|c|c|c|c|c|c|}
\hline $\begin{array}{l}\text { Author, year } \\
\text { No. balones } \\
\text { (ref) }\end{array}$ & Technique & $\begin{array}{l}\text { No. of } \\
\text { cases } \\
\text { Initial/at } \\
3 \text { months }\end{array}$ & $\begin{array}{l}\% \text { EWL } \\
\text { at } 12 \\
\text { weeks }\end{array}$ & $\begin{array}{l}\% \\
\text { patients } \\
\text { with an } \\
E W L>1\end{array}$ & Total WL \\
\hline $\begin{array}{l}\text { Rothstein, } \\
2006 \text { (86) }\end{array}$ & Endobarrier & 100 & $24 \%$ & & \\
\hline $\begin{array}{l}\text { Rdguez-Grunert, } \\
2008 \text { (87) }\end{array}$ & Endobarrier & $=12 / 10$ & $23.6 \%$ & $100 \%$ & $\begin{array}{l}-10.2 \mathrm{~kg} \\
4.3 \mathrm{BMI}\end{array}$ \\
\hline $\begin{array}{l}\text { Tarnoff, } \\
2009 \text { (88) }\end{array}$ & $\begin{array}{l}\text { Endobarrier } \\
\text { Control }\end{array}$ & $\begin{array}{l}25 / 20 \\
14 / 14\end{array}$ & $\begin{array}{l}22 \% \\
5 \%\end{array}$ & & \\
\hline $\begin{array}{l}\text { Gersin, } \\
\quad 2010(84)\end{array}$ & $\begin{array}{l}\text { Endobarrier } \\
\text { Control }\end{array}$ & $\begin{array}{l}21 / 13 \\
26 / 24\end{array}$ & $\begin{array}{l}11.9 \% \\
2.7 \%\end{array}$ & $\begin{array}{l}62 \% \\
17 \%\end{array}$ & $\begin{array}{l}-8.2 \mathrm{~kg} \\
-2.1 \mathrm{~kg}\end{array}$ \\
\hline $\begin{array}{l}\text { Schouten, } \\
2010 \text { (85) }\end{array}$ & $\begin{array}{l}\text { Endobarrier } \\
\text { Control }\end{array}$ & $26 / 22$ & $\begin{array}{l}19 \% \\
6.9 \%\end{array}$ & & $\begin{array}{l}5,5 \mathrm{BMI} \\
1,9 \mathrm{BMI}\end{array}$ \\
\hline
\end{tabular}

EWL: excess weight loss. WL: weight loss. BMI: body mass index.

\section{Removal of the device}

Currently, after the 12 month's device duration, the sleeve is removed using an easy and fast procedure (6-43 minutes) (85-87). Once removed, patients do not have any major discomfort (84).

\section{Results}

The objectives of the procedure include a rapid improvement in the plasma glucose and $\mathrm{HbA} 1 \mathrm{C}$ levels, a reduced reliance on diabetes medicine, a decreased appetite, a satiety-feeling full long after eating and an immediate and continued weight loss.

Early studies in the morbid obese (83-86) confirmed that at 3 months there was a significant decrease in percent EWL versus control group (Table IX) and a significant improvement in plasma glucose parameters, noting that $80 \%$ of patients could abandon the hypoglycemic medication treatment (85). Other co-morbidities such as hypertension or hyperlipidemia can also be corrected (87).

\section{Risks and complications}

The main problems of implantation, extraction and during the procedure were seen with the first generation of Endobarrier (Table X). At the beginning, all the patients had at least one adverse effect during the first week, most of which were abdominal pain and nausea, but limited and transient (85). With the improvements that resulted in the second generation of Endobarrier, mainly mechanism and location of anchor, global complications have been reduced to less than 5\%, concluding that this is currently a safe and reliable technique $(83,85,86)$. Even so, the most frequent complications that remain are nausea,
Table X. Endobarrier first generation complications

\begin{tabular}{|c|c|c|c|}
\hline $\begin{array}{l}\text { Author, year } \\
\text { No. cases } \\
\text { (ref) }\end{array}$ & $\begin{array}{l}\text { Implantation } \\
\text { complications }\end{array}$ & $\begin{array}{l}\text { Early } \\
\text { removal }\end{array}$ & $\begin{array}{l}\text { Extraction } \\
\text { complications }\end{array}$ \\
\hline $\begin{array}{l}\text { Rodríguez-Grunert, } \\
2008 n=12 \\
(87)\end{array}$ & $0 \%$ & $\begin{array}{l}16 \%(2 / 12) \\
2 \text { abdominal } \\
\text { pain }\end{array}$ & $\begin{array}{l}16 \%(2 / 12) \\
1 \mathrm{PT} \\
1 \mathrm{ET}\end{array}$ \\
\hline $\begin{array}{l}\text { Tarnoff, } 2009 \\
\qquad n=25 \text { (88) }\end{array}$ & $0 \%$ & $\begin{array}{l}20 \%(5 / 25) \\
3 \text { UGB } \\
1 \text { migration } \\
\text { of the anchor } \\
10 P\end{array}$ & $0 \%$ \\
\hline $\begin{array}{c}\text { Schouten, } 2010 \\
n=30\end{array}$ & $\begin{array}{l}0 \% \\
4 / 30 \text { could not } \\
\text { introduce due } \\
\text { to technical } \\
\text { problems } \\
26 / 26 \text { implemented } \\
\text { uneventfully } \\
0 \%\end{array}$ & $\begin{array}{l}15 \%(4 / 26) \\
1 \text { migration } \\
1 \text { dislocation of } \\
\text { theanchor } \\
1 \text { PO } \\
1 \text { continuous } \\
\text { abdominal pain }\end{array}$ & $\begin{array}{l}0 \% \\
\text { in }\end{array}$ \\
\hline $\begin{array}{l}\text { Gersin, } 2010 \\
\quad n=21(84)\end{array}$ & $\begin{array}{l}0 \% \\
21 / 21 \text { introduced } \\
\quad \text { uneventfully }\end{array}$ & $\begin{array}{l}38 \%(8 / 21) \\
3 \text { UGB } \\
2 \text { abdominal } \\
\text { pain } \\
2 \text { vomiting } \\
1 \text { pre-existing } \\
\text { disease }\end{array}$ & $0 \%$ \\
\hline
\end{tabular}

PT: pharyngeal tears. ET: esophageal tears. UGB: upper gastrointestinal bleeding. PO: prosthesis obstruction.

vomiting and abdominal pain. Other less common risks include infection, trauma and bleeding, obstruction of the prosthesis, anchoring migration and possibility of perforation, as in the period of treatment as during the maneuver of extraction $(84,88)$.

\section{Valen-Tx}

At the $9^{\text {th }}$ Annual Medtech Investing Conference of the American College of Surgeons Clinical Congress (89) the first clinical trial using the technique of the ValenTx (ValenTx, Inc., Hopkins, Minnesota) was presented. It consisted on a intraluminal $120 \mathrm{~cm}$ length sleeve of gastro-duodenum-jejunal derivation, implanted in the esophagus-gastric junction through mixed endoscopic-laparoscopic technique and was removed only endoscopically, which mimicked the mechanisms of the gastric bypass surgery.

In the study 12 morbid obese patients were selected, introducing the ValenTx during 12 weeks, and achieving an average EWL of $39.5 \%$ in patients who completed the study. It was concluded that it is a safe technique to achieve significant weight loss and helps to control blood glucose levels. 
Table XI. Conclusions

\begin{tabular}{lllllllll}
\hline & BIB & SAIB & HB & BTA & TOGa & EVG & EB \\
\hline Effectiveness & ++ & $++/+++$ & ++ & + & +++ & +++ & +++ \\
$\begin{array}{c}\text { Technique } \\
\text { difficulty }\end{array}$ & ++ & & $++/+++$ & $++/+++$ & + & ++++ & ++++ & +++ \\
Tolerance & ++ & + & ++ & ++++ & +++ & +++ & $++/+++$ \\
Complications & ++ & +++ & $++/+++$ & + & $++/+++$ & $++/+++$ & $++/+++$ \\
\hline
\end{tabular}

BIB: Bioenterics Intragastric Balloon. SAIB: Spatz Adjustable Intragastric Balloon. HB: Heliosphere Bag. BTA: Botulinum Toxin A. TOGa: TransOral Gastroplasty. EVG: Endoluminal Vertical Gastroplasty. EB: EndoBarrier.

Since March 2010 a second study with 30 obese patients has been developed evaluating the feasibility (security, efficiency, indications and contraindications) of this procedure (90).

\section{OTHER TECHNIQUES}

Currently, there are some other procedures that act by electrically stimulating gastric neurons through endoluminal electrodes to decrease the maximum capacity of intake and delayed gastric emptying. The procedures that stand out are the Implantable Gastric Stimulator (Medtronic Transneuronix, Inc., Mount Arlington, New Jersey), the Tantalus System (MetaCure USA Inc., Orangeburg, New York) and the IntraPace (Mountain View, California) (9193).

Other techniques include the Butterfly system (WilsonCook Medical Inc., Winston Salem, North Carolina) $(94,95)$ a small, polyester, butterfly-like, gastric space-occupying device, the BaroSense malabsorptive procedure (Menlo Park, California) and the implantation of tubular membranes into the small intestine (96) which decreases food absorption. All of them seem to be attractive techniques, but with little experience and still in experimental stage.

\section{CONCLUSIONS}

The development of new endoscopic techniques and improvement in existing designs, condition an increasingly important role of the endoscopist in the treatment of obesity. It is essential to identify which endoscopic technique must be used, depending on the results (effectiveness, tolerance, security, adverse effects and risks) and the experience of each medical center.

Comparatively with the Bioenterics balloon (the most extended), the Spatz can offer greater weight loss but with a lower tolerance and more complications, and the Heliosphere Bag gets a similar weight loss but with greater technical difficulty. Other balloons and prosthesis (Ullorex, Semistationary, Silimed, Endogast) still require technical improvements and randomized trials. The injection of bot- ulinum toxin, although safe, seems to be less effective. Suture systems (TOGa, Endoluminal Vertical Gastroplasty and POSE) appear to be effective but are technically more laborious. Malabsorptive procedures (Endobarrier, ValenTX) are somewhat laborious but effective, particularly indicated in obese patients associated with type 2 diabetes (Table XI).

In our opinion, we believe that these techniques should be applied by specifically trained endoscopists in specialized obesity endoscopic centers.

\section{REFERENCES}

1. Obesidad y sobrepeso. OMS. Nota descriptiva $n^{\circ} 311$. Septiembre 2006.

2. WHO. Diet, nutrition and the prevention of chronic diseases. Report of a Joint FAO/WHO Expert consultation. World Health Organ tech Rep Ser 2003;916:1-149.

3. Aranceta-Bartrina J, Serra-Majem L, Foz-Sala M, Moreno-Esteban B, y grupo colaborativo SEEDO. Prevalencia de obesidad en España. Med Clin (Barc) 2005;125(12):460-6.

4. World Health Organization. Obesity: preventing and managing the global epidemic. Report of a WHO consultation on obesity. WHO/NUT/NCD/98.1. WHO Technical Support Series, WHO, Geneva; 1998. p.1-276.

5. Clinical guidelines on the identification, evaluation and treatment of overweight and obesity in adults. The evidence report. National Heart, Lung and Blood Institute Education Initiative (review). Obes Res 1998;6(Supl.2):51S-209S.

6. Glenny AM, O'Meara S, Melville A, Sheldon TA, Wilson C. The treatment and prevention of obesity: a systematic review of the literature (review). Int J Obes Relat Metab Disord 1997;21:715-37.

7. Fobi MAL. The Fobi pouch operation for obesity. Booklet. Quebec, 13th Annual Meeting ASBS, 1996.

8. Baltasar A, Bou R, Del Rio J, Bengochea M, Escrivá C, Miró J, et al. Cirugía bariátrica: resultados a largo plazo de la gastroplastia vertical anillada. ¿Una esperanza frustrada? Cir Esp 1997;62:175-9.

9. Doldi SB, Micheletto G, Perrini MN, Rapetti R. Intragastric balloon: another option for treatment of obesity and morbid obesity. Hepatogastroenterology 2004;51(55):294-7.

10. Carbonelli MG, Fusco MA, Cannistra F, Andreoli A, De Lorenzo A Body composition modification in obese patients treated with intragastric balloon. Acta Diabetol 2003; 40 Supl.1:S261-2.

11. Roman S, Napoléon B, Mion F, Bory RM, Guyot P, D’Orazio H, et al Intragastric balloon for "non-morbid" obesity: a retrospective evaluation of tolerance and efficacy. Obes Surg 2004;14(4):539-44.

12. Espinet E, Merlo J, Durán R, De Ribot X, García V, Valero M, et al Tratamiento endoscópico de la obesidad moderada mediante balón intragástrico. II Congreso Nacional de Endoscopia Digestiva. Madrid 2007.

13. Sciumè C, Geraci G, Pisillo F, Arnone E, Mortillaro M, Modica G. Role of intragastric air filled ballon (Heliosphere bag) in severe obesity. Personal experience. Ann Ital Chir 2009;80(2): 113-7.

14. Tsesmeli N, Coumaros D. Review of endoscopic devices for weight reduction: old and new balloons and implantable prostheses. Endoscopy 2009;41(12):1082-9.

15. Zago S, Kornmuller AM, Agagliato D, Saber B, Ferrari D, Maffeis P, et al. Benefit from bio-enteric Intra-gastric balloon (BIB) to modify lifestyle and eating habits in severely obese patients eligible for bariatric surgery. Minerva Med 2006;97(1):51-64.

16. Genco A, Cipriano M, Bacci V, Cuzzolaro M, Materia A, Raparelli $\mathrm{L}$, et al. BioEnterics Intragastric Balloon (BIB): a short-term, double- 
blind, randomised, controlled, crossover study on weight reduction in morbidly obese patients. Int J Obes (Lond) 2006;30(1):129-33.

17. De Waele B, Reynaert H, Urbain D, Willems G. Intragastric balloons for preoperative weight reduction. Obes Surg 2000;10:58-60.

18. Evans JD, Scott MH. Intragastric balloon in the treatment of patients with morbid obesity. Br J Surg 2001;88:1245-8.

19. Alfalah H, Philippe B, Ghazal F, Jany T, Arnalsteen L, Romon M, et al. Intragastric balloon for preoperative weight reduction in candidates for laparoscopic gastric bypass with massive obesity. Obes Surg 2006;16:147-50.

20. Nieben OG, Harboe H. Intragastric balloon as an artificial bezoar for treatment of obesity. Lancet 1982;1:198-9.

21. Schapiro M, Benjamin S, Blackburn G, Frank B, Heber D, Kozarek R, et al. Obesity and the gastric balloon: a comprehensive workshop. Tarpon Springs, Florida, March 19-21, 1987. Gastrointest Endosc 1987;33:323-7.

22. Bonazzi P, Petrelli MD, Lorenzini I, Peruzzi E, Nicolai A, Galeazzi R. Gastric emptying and intragastric balloon in obeses patients. Eur Rev Pharmacol Sci 2005;9(5 Supl.1):15-21.

23. Mion F, Napoleon B, Roman S, Malvoisin E, Trepo F, Pujol B, et al. Effects of intragastric balloon on gastric emptying and plasma ghrelin levels in non-morbid obese patients. Obes Surg 2005;15(4):510-6.

24. Whalen CH, Bastens B, Herve J, Malmendier C, Dallemagne B, Jehaes $\mathrm{C}$, et al. The BioEnterics Intragastric Balloon (BIB): how to use it. Obes Surg 2001;11:524-7.

25. Genco A, Bruni T, Doldi SB, Forestieri P, Marino M, Busetto L, et al. BioEnterics Intragastric Balloon: The Italian Experience with 2.515 patients. Obes Surg 2005;15(8):1161-4.

26. García V, Espinet E, Valero M, Aparici A, Martínez E, Merlo J. Importancia de la enfermería en el balón intragástrico endoscópico. XV Jornada Nacional de la AEEED. Murcia 2006.

27. Jenkins JT, Galloway DJ. A simple novel technique for intragastric balloon retrieval. Obes Surg 2005;15(1):122-4.

28. Dumonceau JM. Evidence-based review of the Bioenterics intragastric balloon for weight loss. Obes Surg 2008;18(12):1611-7.

29. Mathus-Vliegen EM, Tytgat GN. Intragastric balloon for treatmentresistant obesity: safety, tolerance, and efficacy of 1-year balloon treatment followed by a 1 -year balloon-free follow-up. Gastrointest Endosc 2005;61(1):19-27.

30. Al-Momen A, El-Mogy I. Intragastric balloon for obesity: a retrospective evaluation of tolerance and efficacy. Obes Surg 2005;15(1):101-5.

31. Herve J, Wahlen CH, Schaeken A, Dallemagne B, Dewandre JM, Markiewicz $\mathrm{S}$, et al. What becomes of patients one year after the intragastric balloon has been removed? Obes Surg 2005;15(6):864-70.

32. Totte E, Hendrickx L, Pauwels M, Van Hee R. Weight reduction by means of intragastric device: experience with the bioenterics intragastric balloon. Obes Surg 2001;11(4):519-23.

33. Sallet JA, Marchesini JB, Paiva DS, Komoto K, Pizani CE, Ribeiro ML, et al. Brazilian multicenter study of the intragastric balloon. Obes Surg 2004;14(7):991-8.

34. Loffredo A, Cappuccio M, De Luca M, de Werra C, Galloro G, Naddeo $\mathrm{M}$, et al. Three years experience with the new intragastric balloon, and a preoperative test for success with restrictive surgery. Obes Surg 2001;11(3):330-3.

35. Busetto L, Segato G, De Luca M, Bortolozzi E, MacCari T, Magon A, et al. Preoperative weight loss by intragastric balloon in super-obese patients treated with laparoscopic gastric banding: a case-control study. Obes Surg 2004;14(5):671-6.

36. Escudero-Sanchís A, Catalán Serra I, Gonzalvo Sorribes J, Bixquet Jiménez M, Navarro López L, Herrera García L, et al. Efectividad, seguridad y tolerancia del balón intragástrico asociado a una dieta hipocalórica para la reducción de peso en pacientes obesos. Rev Esp Enferm Dig 2008;100(6): 349-54
37. Busetto L, Enzi G, Inelmen EM, Costa G, Negrin V, Sergi G, et al Obstructive sleep apnea syndrome in morbid obesity: effects of intragastric balloon. Chest 2005;128(2):618-23.

38. Frutos MD, Morales MD, Luján J, Hernández Q, Valero G, Parrilla I. Intragastric balloon reduces liver volume in super-obese patients, facilitating subsequent laparoscopic gastric bypass. Obes Surg 2007;17(2):150-4

39. Puglisi F, Capuano P, Veneziani N, Lobascio P, Di Franco AD, Lograno $\mathrm{G}$, et al. Tachyarrythmia due to atrial fibrillation in an intragastric balloon carrier: coincidence or consequence? Obes Surg 2005;15(5):716-8.

40. Vanden EF, Urbain P. Small intestine gastric balloon impaction treated by laparoscopic surgery. Obes Surg 2001;11(5):646-8.

41. Bona D, Enrini R, Bonavina L. Intestinal obstruction caused by migration of intragastric device used for the treatment of obesity. Chir Ital 2004;56(2):285-8

42. Kim WY, Kirkpatrick UJ, Moody AP, Wake PN. Large bowel impaction by the BioEnterics Intragastric Balloon necessitating surgical intervention. Ann R Coll Surg Engl 2000;82(3):202-4.

43. Rodríguez-Hermosa JI, Roig-García J, Gironès-Vilà J, Ruiz-Feliú B, Ortiz-Ballujera P, Ortiz-Durán MR, et al. Gastric necrosis: a possible complication of the use of the intragastric balloon in a patient previously submitted to Nissen fundoplication. Obes Surg 2009;19(10): 1456-9.

44. Nijhof HW, Steenvoorde P, Tollenaar RA. Perforation of the esophagus caused by the insertion of an intragastric balloon for the treatment of obesity. Obes Surg 2006;16(5):667-70.

45. Laurent B, Charles D, Laurent M. Covered gastric perforation by the BioEnterics Intragastric Balloon. J Clin Gastroenterol 2001;33(4):344-5.

46. Giardiello C, Cristiano S, Cerbone MR, Troiano E, Iodice G, Sarrantonio G. Gastric perforation in an obese patient with an intragastric balloon, following previous fundoplication. Obes Surg. 2003;13(4): 658-60.

47. Ballare M, Orsello M, Del Piano M. A case of death after insertion of an intragastric balloon for treatment of morbid obesity. Dig Liver Dis 2004;36(7):499.

48. Spyropoulos C, Katsakoulis E, Mead N, Vagenas K, Kalfarentzos F. Intragastric balloon for high-risk super-obese patients: a prospective analysis of efficacy. Surg Obes Relat Dis 2007;3(1):78-83.

49. López-Nava G, Rubio MA, Prados S, Pastor G, Cruz MR, Companioni $\mathrm{E}$, et al. BioEnterics Intragastric Balloon (BIB). Single ambulatory Spanish experience with 714 consecutive patients treated with one or two consecutive balloons. Obes Surg 2011;1(1):5-9.

50. Genco A, Cipriano M, Bacci V, Maselli R, Paone E, Lorenzo M, et al. Intragastric balloon followed by diet vs intragastric balloon followed by another balloon: a prospective study on 100 patients. Obes Surg 2010;20(11):1496-500.

51. Martin CK, Bellanger DE, Rau KK, Coulon S, Greenway FL. Safety of the Ullorex Oral Intragastric Balloon for the treatment of obesity. J Diabetes Sci Technol 2007;1(4):574-81.

52. Malik A. Endoluminal and transluminal surgery: current status and future possibilities. Surg Endosc 2006;20(8):1179-92.

53. Machytka E, Klvana P, Kornbluth A, Peikin S, Mathus-Vliegen L, Gostout $\mathrm{C}$, et al. Adjustable Intragastric Balloons: a 12-month pilot trial in endoscopic weight loss management. Obes Surg 2011;21(10):1499507

54. Forestieri P, De Palma GD, Formato A, Giuliano ME, Monda A, Pilone $\mathrm{V}$, et al. Heliosphere Bag in the treatment of severe obesity: preliminary experience. Obes Surg 2006;16(5):635-7.

55. De Castro ML, Morales MJ, Del Campo V, Pineda JR, Pena E, Sierra $\mathrm{JM}$, et al. Efficacy, safety, and tolerante of two types of intragastric balloons placed in obese subjects: a double-blind comparative study. Obes Surg 2010;20(12):1642-6.

56. Sciumè C, Geraci G, Pisillo F, Arnone E, Mortillaro M, Modica G. Role of intragastric air filled ballon (Heliosphere bag) in severe obesity. Personal experience. Ann Ital Chir 2009;80(2):113-7. 
57. Trande P, Mussetto A, Mirante VG, De Martines E, Olivetti G, Conigliaro RL, et al. Efficacy, tolerance and safety of new intragastric airfilled balloon (Heliosphere BAG) for obesity: the experience of 17 cases. Obes Surg 2010; 20(9):1227-30.

58. Lecumberri E, Krekshi W, Matía P, Hermida C, De la Torre NG, Cabrerizo L, et al. Effectiveness and safety of air-filled Balloon Heliosphere BAG in 82 consecutive obese patients. Obes Surg 2011;21(10):150812

59. Lopasso FP, Sakai P, Gazi BM, Artifon EL, Kfouri C, Souza JP, et al. A pilot study to evaluate the safety, tolerance and efficacy of a novel stationary antral balloon (SAB) for obesity. J Clin Gastroenterol 2008;42:48-53.

60. Carvalho GL, Barros CB, Okazaki M, Novaes ML, Albuquerque PP, Wakiyama $\mathrm{C}$, et al. An improved intragastric balloon procedure using a new balloon: preliminary analysis of safety and efficiency. Ober Surg 2009;19(2):237-42.

61. Gaggioti G, Tack J, Garrido AB Jr, Palau M, Cappelluti G, Di Matteo F. Adjustable totally implantable intragastric prótesis (ATIIP)-Endogast for treatment of morbid obesity: one-year follow-up of a multicenter prospective clinical survey. Obes Surg 2007;17(7):949-56.

62. Topazian M, Camillero M, De la Mora-Levy J, Enders FB, Foxx-Orenstein AE, Levy MJ, et al. Endoscopic ultrasound-guided gastric botulinum toxin injections in obese subjects: a pilot study. Obes Surg 2008;18(4):401-7

63. Foschi D, Lazaron M, Sangaletti O, Corsi F, Trabucchi E, Bianchi Porro G. Effects of intramural administration of Botulinum Toxin A on gastric emptying and eating capacity in obese patients. Dig Liver Dis 2008;40(8):667-72.

64. Foschi D, Corsi F, Lazzaroni M, Sangaletti O, Riva P, La Tartara G, et al. Treatment of morbid obesity by intraparietogastric administration of botulinum toxin: a randomized, double-blind, controlled study. Int J Obes (Lond) 2007;31(4):707-12.

65. Rollnik JD, Meier PN, Manns MP, Goke M. Antral injections of botulinum A toxin for the treatment of obesity. Ann Intern Med 2003; 138:359-60.

66. Mittermair R, Keller C, Geibel J. Intragastric injection of botulinum toxin for the treatment of obesity. Obes Surg 2007;17(6):732-6.

67. Júnior AC, Savassi-Rocha PR, Coelho LG, Spósito MM, Albuquerque W, Diniz MT, et al. Botulinum A toxin injected into the gastric wall for the treatment of class III obesity: a pilot study. Obes Surg 2006;16(3):335-43.

68. Albani G, Petroni ML, Mauro A, Liuzzi A, Leéis G, Verti B, et al. Safety and efficacy of therapy with botulinum toxin in obesity: a pilot study. J Gastroenterol 2005;40(8):833-5.

69. Gui D, Mingrone G, Valenza V, Spada PL, Mutignani M, Runfola M, et al. Effect of botulinum toxin antral injection on gastric emptying and weight reduction in obese patients: a pilot study. Aliment Pharmacol Ther 2006;23:675-80.

70. García-Compean D, Mendoza-Fuerte E, Martínez JA, Villarreal I, Maldonado $\mathrm{H}$. Endoscopic injection of botulinum toxin in the gastric antrum for the treatment of obesity. Results of a pilot study. Gastroenterol Clin Biol 2005;29(8-9):789-91.

71. Osio M, Mailland E, Muscia F, Nascimbene C, Vanotti A, Bana C, et al. Botulinum neurotoxin-A does not spread to distant muscles after intragastric injection: A double-blind single-fiber electromyography study. Muscle Nerve. 2010;42(2):165-9.

72. García-Compean D, Maldonado Garza H. Intragastric injection of botulinum toxin for the treatment of obesity. Where are we? World J Gastroenterol 2008;14(12):1805-9.

73. Devière J, Ojeda Valdes G, Cuevas Herrera L, Closset J, Le Moine O, Eisendrath P, et al. Safety, feasibility and weight loss after transoral gastroplasty: first human multicenter study. Surg Endosc 2008;22(3):589-98

74. Moreno C, Closset J, Dugardeyn S, Baréa M, Medí A, Collignon L, et al. Transoral gastroplasty is safe, feasible, and induces significant weight loss in morbidly obese patients: results of the second human pilot study. Endoscopy 2008;40(5):406-13.

75. Chiellini C, Iaconelli A, Familiari P, Riccioni ME, Castagneto M, Nann $\mathrm{G}$, et al. Study of the effects of transoral gastroplasty on insulin sensitivity and secretion in obese subjects. Nutr Metab Cardiovasc Dis 2010;20(3):202-7.

76. Closset J, Germanota D, Loi P, Medhi A, Moreno C, Devière J. Laparoscopic gastric bypass as a revision procedure alter transoral gastroplasty. Obes Surg 2011;21(1):1-4.

77. Awan AN, Swain CP. Endoscopic vertical band gastroplasty with an endoscopic sewing machine. Gastrointest Endosc 2002;55(2):254-6.

78. Hu B, Cheng SC, Sun LC, Kawashima K, Yamamoto T, Cotton PB, et al. Transoral obesity surgery: endoluminal gastroplasty with an endoscopic suture device. Endoscopy 2005;37(5):411-4.

79. Kantsevoy SV, Hu B, Jagannath SB, Isakovich NV, Chung SS, Cotton $\mathrm{PB}$, et al. Technical feasibility of endoscopic gastric reduction: a pilot study in a porcine model. Gastrointest Endosc 2007;65(3):510-3.

80. Fogel R, De Fogel J, Bonilla Y, De La Fuente R. Clinical experience of transoral suturing for an endoluminal vertical gastroplasty: 1year follow-up in 64 patients. Gastrointest Endosc 2008;68(1): 51-8.

81. Brethauer SA, Chand B, Schauer PR, Thompson CC. Transoral gastric volume reduction for weight management: technique and feasibility in 18 patients. Surg Obes Relat Dis 2010;6(6):689-94.

82. Fishman E, Melanson D, Lamport R, Lavine A. A novel endoscopic delivery system for placement of a duodenal-jejunal implant for the treatment of obesity and type 2 diabetes. Conf Proc IEEE Eng Med Biol Soc 2008;2501-3.

83. Gersin KS, Keller JE, Stefanidis D, Simms CS, Abraham DD, Deal SE, et al. Duodenal-jejunal bypass sleeve: a totally endoscopic device for the treatment of morbid obesity. Surg Innov 2007;14(4):275-8.

84. Gersin KS, Rothstein RI, Rosenthal RJ, Stefanidis D, Deal SE, Wuwada TS, et al. Open-label, sham-controlled trial of an endoscopic duodenojejunal bypass liner for preoperative weight loss in bariatric surgery candidates. Gastrointest Endosc 2010;71(6):976-82.

85. Schouten R, Rijs CS, Bouvy ND, Hameeteman W, Koek GH, Janssen IM, et al. A multicenter, randomized efficacy study of the EndoBarrier Gastrointestinal Liner for presurgical weight loss prior to bariatric surgery. Ann Surg 2010;251(2):236-43

86. Rothstein. The role of endoscopy in the management of the bariatric patient. VI Curso Internacional de Endoscopia Digestiva Terapéutica. Pamplona, 3-5 Abril 2008.

87. Rodríguez-Grunert L, Galvao Neto MP, Alamo M, Cardoso Ramos A, Brante Baez P, Tarnoff M. First human experience with endoscopically delivered and retrieved duodenal-jejunal bypass sleeve. Surg Obes Relat Dis 2008;4:55-9.

88. Tarnoff M, Rodríguez L, Escalona A, Ramos A, Neto M, Alamo M, et al. Open label, prospective, randomized controlled trial of an endoscopic duodenal-jejunal bypass sleeve versus low calorie diet for pre-operative weight loss in bariatric surgery. Surg Endosc 2009;23:650-6.

89. Dann, M. 9th Annual Medtech investing Conference. American College of Surgeons Clinical Congress. Minnesota. USA. 2009.

90. Rumbaut R, Horgan S, Swain P, González L, Merino R. A single center feasibility trial of the safety and efficacy of the ValenTx Endo Bypass system in obese subjects. Hospital San José. Monterrey. Méjico 2010 (study ongoing)

91. De Luca M, Segato G, Busetto L, Favretti F, Aigner F, Weiss H, et al. Progress in implantable gastric stimulation: summary of results of the European multi-center study. Obes Surg 2004;14(1):33-9.

92. Favretti F, De Luca M, Segato G, Busetto L, Ceoloni A, Magon A, et al. Treatment of morbid obesity with the Transcend Implantable Gastric Stimulator (IGS): a prospective survey. Obes Surg 2004;14(5): 666-70. 
93. Liu J, Hou X, Song G, Cha H, Yang B, Chen JD. Gastric electrical stimulation using endoscopically placed mucosal electrodes reduces food intake in humans. Am J Gastroenterol 2006;101(4):798-803.

94. Hashiba K, Brasil H, Wada A, et al. Experimental study of an alternative endoscopic method for the treatment of obesity: the butterfly technique. Gastrointest Endosc 2001; 53:AB112.
95. Hashiba K, Hassegawa RT, Wada S, et al. Plastic device (Butterfly) for endoscopic treatment of obesity: new design and operation. Gastrointest Endosc 2003;57:AB181.

96. Kelleher B, Stone C, Tsukashima R, et al. Implantation of a tubular membrane in the small intestine. Gastrointest Endosc 2004;59: AB151. 